\title{
Yield and Water Productivity Response of Rice to Application of Urban Compost
}

\author{
K. Avil Kumar*, K. Sadasiva Rao, M. Uma Devi and D. Sandeep Kumar
}

Institute of Agricultural Engineering and Technology, College of Agriculture, Professor

Jayashankar Telangana State Agricultural University, Rajendranagar, Hyderabad, India

*Corresponding author

\section{A B S T R A C T}

\section{Keywords}

Inorganic fertilizers,

Urban compost,

Rice yield, Harvest index, Water

productivity

\section{Article Info}

Accepted:

15 November 2019

Available Online:

10 December 2019
The present research was conducted with an objective to study the influence of varying rates of urban compost in combination with recommended dosage of fertilizers (RDF) on yield and yield components of rice variety, BPT 5204. Field experiments were carried out for three years during rabi 2012-2015. The experiment was laid out in a randomized complete block design with three replicates. The urban compost was procured from two different dumping yard sources of Hyderabad. One is from Jawahar nagar dumping yard, which was established during 2002 and the second source is Autonagar, which is a more than 50 years old dumping yard. There were eight treatments comprising recommended dose of N,P,K (120:60:40 N, $\mathrm{P}_{2} \mathrm{O}_{5}$ and $\left.\mathrm{K}_{2} \mathrm{O} \mathrm{kg} \mathrm{ha}{ }^{-1}\right), \mathrm{RDF}+$ Farm Yard Manure $\left(10 \mathrm{t} \mathrm{ha}^{-1}\right)$, three rates of urban compost from Jawahar nagar $\left(2.5,5\right.$ and $\left.10 \mathrm{t} \mathrm{ha}^{-1}\right)+\mathrm{RDF}$ and three rates of urban compost from Autonagar $\left(2.5,5\right.$ and $\left.10 \mathrm{t} \cdot \mathrm{ha}^{-1}\right)+\mathrm{RDF}$. Grain yield, straw yield, total dry matter yield, harvest index and water productivity were determined. Pooled data analysis results revealed that the beneficial effects of application of urban compost were enhanced at increased rates of application. The performance of rice was superior on the field fertilized with RDF plus $10 \mathrm{t} \mathrm{ha}^{-1}$ urban compost from Jawahar nagar which was comparable to RDF plus $10 \mathrm{tha}^{-1}$ urban compost from Autonagar. The highest grain yield $\left(6,095 \mathrm{~kg} \mathrm{ha}^{-1}\right)$, straw yield $\left(9926 \mathrm{~kg} \mathrm{ha}^{-1}\right)$, total dry matter yield $\left(16021 \mathrm{~kg} \mathrm{ha}^{-1}\right)$, harvest index $(37.63 \%)$ and water productivity $\left(7.73 \mathrm{~kg} \mathrm{ha}^{-1}\right)$ were recorded in plots applied with $\mathrm{RDF}+10 \mathrm{tha}^{-1}$ urban compost from Jawahar nagar. Therefore, it is evident that yield of rice can be increased significantly with the combined use of urban compost and chemical fertilizers.

\section{Introduction}

Rice (Oryza sativa L.) is an important staple food for billions of people. To assure food security in the rice-consuming countries of the world, farmers must produce more rice of better quality to meet the demands of consumers in coming years (Peng and Yang, 2003). However, the average yield of rice has been stagnant and remained lower than the production potential. The causes of low yield of rice include low soil fertility, low organic 
matter status, conventional cultivation system, improper management and the hazards of the climatic aberration. Soil fertility deterioration has become a major constraint to higher crop production. The increasing land use intensity with inadequate and unbalanced use of chemical fertilizers together with little or no use of organic manures have caused severe fertility deterioration of soils resulting in stagnating or even declining of crop productivity. Since organic matter is the fundamental resource for improving soil health, management of soil organic matter has now become a major issue in dealing with the problem of soil fertility and productivity.

A suitable combination of organic and inorganic source of nutrients is necessary for sustainable agriculture that can ensure food production with high quality (Reganold et al., 1990). Integrated use of organic manure and chemical fertilizer would be quite promising not only in providing greater stability in production, but also in maintaining better soil fertility (Nambiar, 1991). Thus, it is necessary to find out site specific integrated use of nutrients from organic and inorganic sources for sustainable crop production.

With the development of modern societies in which raw consumerism and the culture of "throwaway" is on the agenda, the problem of urban solid waste is becoming ever greater. Land filling disposal of wastes contributes flooding, breeding of insect and rodent vectors, the spread of diseases and polluting ground water quality. Using a good strategy such as composting process, solid wastes can be converted into useful products for improvement of soils properties (Hashemimajd et al., 2004; Sohrabi Yourtchi et al., 2013). Urban compost can be considered as a valuable source of nitrogen $(\mathrm{N})$, phosphorous (P), essential trace elements, and organic matter that will improves soil physical properties and plant nutritional status (Bertoldi et al., 1996; Zinati et al., 2004; Kabirinejad and Hoodaji 2012). Furthermore, use of urban compost can reduce the agricultural demands for water, fertilizers and pesticides (Hoitink et al., 1997; Weltzien, 1989; Sahin and Bolukbasi, 2009). Composting also extends the life of the municipal landfill by diverting organic materials from landfills to agricultural lands.

The highest biomass yield of boro rice (BRRI dhan50) viz., $925 \mathrm{~g} \mathrm{~m}^{-2}$ was recorded in the plants applied with 10 ton $\mathrm{ha}^{-1}$ of MSW compost and $100 \%$ RDF. The same treatment demonstrated the highest grain yield (6.3t/ha) and straw yield (9.90 $\mathrm{t} \mathrm{ha}^{-1}$ ). Only MSW application compost even at 20 ton/ha was not comparable with recommended dose of fertilizer in producing rice yield (Aktar et al., 2018). Kavitha and Subramanian, 2007 reported that the growth attributes viz., plant height, leaf area index, number of tillers and dry matter production increased significantly due to the application of enriched municipal solid waste compost (EMSWC). The highest grain yield and straw yield were observed in the treatment combination of $25 \%$ of enriched compost and $75 \%$ of recommended dose of inorganic fertilizer with value of 5.22 and $8.65 \mathrm{t} \mathrm{ha}^{-1}$, respectively. Application of $5 \mathrm{t}$ $\mathrm{ha}^{-1}$ enriched MSWC in combination with $25 \% \mathrm{~N}$ through inorganic fertilizer recorded grain yield of $4.33 \mathrm{t} \mathrm{ha}^{-1}$. The lowest grain yield (3.78 $\left.\mathrm{t} \mathrm{ha} \mathrm{ha}^{-1}\right)$ was recorded in treatment where the compost was applied alone. The potential of municipal solid waste compost (MSWC) was evaluated for rice cultivar using municipal solid waste compost (MSWC) and cow dung manure (CDM), with or without urea (U), and fertilizers (F). Dry matter accumulation was highest with CDM + U, followed by MSWC + $\mathrm{U}$ and F. Panicle length was the largest and thousand-grain-weight were the highest for F. 
Application of CDM alone gave 30\% higher grain yield over MSWC but the latter, along with urea, increased grain yield by $49 \%$ over MSWC alone (Bhattacharyya and Chakraborty 2003). Thus, there has been a growing interest in the use of urban compost as a source of nutrients in rice. This trial was, therefore, conducted to study the effect of combined application of urban compost and inorganic fertilizers on the growth and yield of rice variety BPT 5204.

\section{Materials and methods}

Field experiments were conducted at College farm, PJTSAU, Rajendranagar to investigate the effect of urban compost in combination with inorganic fertilizers on the yield and water productivity of rice during rabi 20122015. Experiments were laid out in a randomized complete block design (RCBD) with three replicates. Rice variety BPT 5204 was used for the study. The net plot size was $13.0 \mathrm{~m}$ x $6.0 \mathrm{~m}$. Twenty five days old nursery of was transplanted in standing water with 20 $\mathrm{cm}$ row to row and $15 \mathrm{~cm}$ plant to plant distance. The different treatments used were:

T1- Recommended dose of N,P,K (RDF)

T2-RDF+ Farm Yard Manure (10 t/ha)

T3- RDF + Urban Compost - I (2.5 t/ha)

T4- RDF + Urban Compost - I (5.0 t/ha)

T5- RDF + Urban Compost - I (10.0 t/ha)

T6-RDF+ Urban Compost -II (2.5 t/ha)

T7- RDF+ Urban Compost -II (5.0 t/ha)

T8- RDF + Urban Compost -II (10.0 t/ha)

The urban compost was procured from two different dumping yard of Hyderabad. One from Jawahar nagar (Urban Compost - I) where urban waste is managed in a scientific way by segregating the different materials, recycling of non biodegradable waste materials (plastic, metals, etc.) and composting bio degradable waste. Other from Autonagar (Urban Compost -II) which is a more than 50 years old dumping yard, where urban waste was just dumped without segregating bio degradable and non biodegradable waste material. The compost was formed naturally over a period of time. The compost from this place was collected just by screening.

The compost from both the sources were applied at three different rates $(2.5,5$ and $10 \mathrm{t}$ $\mathrm{ha}^{-1}$ ) along with recommended dose of N,P,K (120:60:40 N, $\mathrm{P}_{2} \mathrm{O}_{5}$ and $\left.\mathrm{K}_{2} \mathrm{O} \mathrm{kg} \mathrm{ha}{ }^{-1}\right)$. All other agronomic practices were kept uniform to keep the crop free from pests. At maturity grain yield, straw yield, total dry matter yield, harvest index and water productivity were measured. Data pertaining to various parameters were tabulated and subjected to statistical analysis for interpretation of results.

\section{Results and Discussion}

Analysis of data showed that all the yield and water productivity of rice was significantly affected by urban compost in combination with inorganic fertilizers (Table 1). Results indicated that the beneficial effects of application of urban compost were enhanced at increased rates of application (Fig. 1).

\section{Grain yield ( $\left.\mathrm{kg} \mathrm{ha}^{-1}\right)$}

The analysis of data after rice crop indicated that the plots fertilized with urban compost from Jawahar nagar (Urban Compost-I) @ $10.0 \mathrm{t} \mathrm{ha}^{-1}$ along with RDF of 120:60:40 N, $\mathrm{P}_{2} \mathrm{O}_{5}$ and $\mathrm{K}_{2} \mathrm{O} \mathrm{kg}^{-1}$ ha ${ }^{-1}$ recorded significantly higher grain yield of $6,095 \mathrm{~kg} \mathrm{ha}^{-1}$ followed by the plots applied with urban compost from 
Autonagar (Urban Compost -II) @ $10.0 \mathrm{t} \mathrm{ha}^{-1}$ along with $\mathrm{RDF}$ of 120:60:40 N, $\mathrm{P}_{2} \mathrm{O}_{5}$ and $\mathrm{K}_{2} \mathrm{O} \mathrm{kg} \mathrm{ha} \mathrm{kg}^{-1}$ and were on par with urban compost application @ 5.0 t ha ${ }^{-1}$ and significantly superior over rest of the treatments. Significantly lower yield of 4,635 $\mathrm{kg} \mathrm{ha}^{-1}$ was recorded in plots applied with RDF of 120:60:40 N, $\mathrm{P}_{2} \mathrm{O}_{5}$ and $\mathrm{K}_{2} \mathrm{O} \mathrm{kg} \mathrm{ha}{ }^{-1}$ and was on par with application of FYM $10 \mathrm{t}$ $\mathrm{ha}^{-1}$ and urban compost of both sources @ 2.5 $\mathrm{t} \mathrm{ha}^{-1}$. The pronounced effect of yield of rice might be due to the decomposition of compost which forms easily available nutrients like $\mathrm{N}, \mathrm{P}, \mathrm{K}$ as well as micronutrients such as $\mathrm{Zn}, \mathrm{Fe}, \mathrm{Mn}$ and $\mathrm{Cu}$. Compost act as a slow releasing fertilizer and it supplies plant nutrients slowly but continuously (Kavitha and Subramanian 2007).

\section{Straw yield $\left(\mathrm{kg} \mathrm{ha}^{-1}\right)$}

Application of Urban Compost-I @ $10.0 \mathrm{t} \mathrm{ha}^{-1}$ along with RDF produced significantly higher straw yield over other treatments. The straw yield due to the different treatments ranged from 12,838 to $16,021 \mathrm{~kg} \mathrm{ha}^{-1}$. The highest straw yield of $16,021 \mathrm{~kg} \mathrm{ha}^{-1}$ was obtained in the treatment $\mathrm{T}_{5}$ (Urban Compost-I @ $10.0 \mathrm{t}$ $\left.\mathrm{ha}^{-1}+\mathrm{RDF}\right)$. The lowest straw yield of 12,838 $\mathrm{kg} \mathrm{ha}{ }^{-1}$ was recorded in the treatment $\mathrm{T}_{1}$ (RDF). The straw yields of rice in all the treatments were always higher to the corresponding grain yields. Rice plants treated with urban compost encouraged rapid vegetative growth leading to the production of higher straw yield.

\section{Total dry matter yield (kg ha $\left.{ }^{-1}\right)$}

Maximum total dry matter yield $(16,021 \mathrm{~kg}$ $\mathrm{ha}^{-1}$ ) was recorded in $\mathrm{T}_{5}$ (Urban Compost-I @ $\left.10.0 \mathrm{t} \mathrm{ha}^{-1}+\mathrm{RDF}\right)$ which was statistically at par with $\mathrm{T}_{8}$ (Urban Compost-II @ $10.0 \mathrm{t} \mathrm{ha}^{-1}$ + RDF). Significantly lowest total dry matter yield $\left(12,837.67 \mathrm{~kg} \mathrm{ha}^{-1}\right)$ was obtained from
$\mathrm{T}_{1}$ (RDF). Higher total dry matter yield might be due to the increase in growth and yield attributes. Maximum dry matter accumulation recorded from plots receiving urban compost could be due to better mineralization of urban compost and synchronization of nutrient release with crop growth stage, this timely nutrient availability might have increased the crop growth rate and dry matter partitioning in stem and leaves.

\section{Harvest index (\%)}

Harvest index (HI) is the ratio of grain yield to total above ground plant yield. According to a pooled data, urban compost I @ $10 \mathrm{t} \mathrm{ha}^{-1}+$ RDF had highest HI (37.63\%) followed by urban compost II @ $10 \mathrm{t} \mathrm{ha}^{-1}+\mathrm{RDF}$ (36.67 $\%)$. Higher yield and harvest index of urban compost I@ $10 \mathrm{t} \mathrm{ha}^{-1}$ + RDF indicates better partitioning of photosynthetic substance to economic yield. Appreciably high harvest index shows the efficiency of converting biological yield into economic yield.

\section{Water productivity $\left(\mathrm{kg} \mathrm{ha}^{-1}\right)$}

Analysis of the effects of treatments on rice water productivity indicated that water productivity, kilograms of grain yield produced per millimeter of water used, differed significantly among treatments in all years. The lowest water productivity of 6.01 $\mathrm{kg} \mathrm{ha}^{-1}$ was obtained from the treatment $\mathrm{T}_{1}$ (RDF). The treatment $\mathrm{T}_{5}$ (Urban Compost-I @ $\left.10.0 \mathrm{t} \mathrm{ha}^{-1}+\mathrm{RDF}\right)$ consistently had the highest water productivity of $7.73 \mathrm{~kg} \mathrm{ha}^{-1}$. Our results indicated that urban compost application increased water productivity in all three years compared to the application of only RDF. Increased water productivity in the urban compost treatment observed here was due to increased supply of nutrient and improved soil properties that are crucial to higher crop root growth and increased productivity (Schlegel et al., 2015). 
Table 1: Effect of urban compost on grain, straw, total dry matter production, harvest index and water productivity of rice during rabi 2012- 15

\begin{tabular}{|c|c|c|c|c|c|c|c|c|c|c|c|c|}
\hline \multirow[t]{2}{*}{ Treatments } & \multicolumn{4}{|c|}{ Grain yield $\left(\mathrm{kg} \mathrm{ha}^{-1}\right)$} & \multicolumn{4}{|c|}{ Straw yield $\left(\mathrm{kg} \mathrm{ha}^{-1}\right)$} & \multicolumn{4}{|c|}{ Total dry matter yield $\left(\mathrm{kg} \mathrm{ha}^{-1}\right)$} \\
\hline & $2012-13$ & $\begin{array}{c}2013- \\
14\end{array}$ & $2014-15$ & mean & $\begin{array}{c}2012- \\
13\end{array}$ & $\begin{array}{c}2013- \\
14\end{array}$ & $\begin{array}{c}2014- \\
15\end{array}$ & mean & $\begin{array}{c}2012- \\
13\end{array}$ & 2013-14 & $2014-15$ & mean \\
\hline T1-RDF & 2684 & 5351 & 5869 & 4635 & 8024 & 9368 & 7217 & 8203 & 10708 & 14719 & 13086 & 12838 \\
\hline T2-FYM (10.0) & 3009 & 5678 & 6671 & 5119 & 8417 & 9450 & 8510 & 8792 & 11426 & 15128 & 15181 & 13912 \\
\hline T3-UC-I (2.5) & 2556 & 5419 & 6386 & 4787 & 8161 & 9872 & 8000 & 8678 & 10718 & 15291 & 14386 & 13465 \\
\hline T4-UC-I (5.0) & 2911 & 6114 & 7294 & 5440 & 9351 & 9967 & 8919 & 9412 & 12262 & 16081 & 16213 & 14852 \\
\hline T5-UC-I (10.0) & 3982 & 6754 & 7550 & 6095 & 9577 & 11383 & 8817 & 9926 & 13559 & 18137 & 16367 & 16021 \\
\hline T6-UC-II (2.5) & 2783 & 5379 & 5984 & 4715 & 8338 & 10240 & 7489 & 8689 & 11121 & 15618 & 13474 & 1340 \\
\hline T7-UC-II (5.0) & 3294 & 5882 & 6584 & 5253 & 9292 & 10294 & 8374 & 9320 & 12586 & 16176 & 14958 & 14573 \\
\hline T8-UC-II (10.0) & 3736 & 6291 & 6958 & 5662 & 9746 & 11111 & 8170 & 9676 & 13483 & 17402 & 15128 & 15338 \\
\hline SE. $\mathbf{m}$ & 185 & 112 & 334 & 140 & 416 & 374 & 390 & 180 & 435 & 393 & 578 & 260 \\
\hline CD & 561 & 341 & 1015 & 426 & 1263 & 1134 & NS & 546 & 1320 & 1193 & 1754 & 790 \\
\hline
\end{tabular}

\begin{tabular}{|c|c|c|c|c|c|c|c|c|}
\hline Treatments & \multicolumn{3}{|c|}{ Harvest index yield (\%) } & \multicolumn{4}{c|}{ Water productivity* $\left.\mathbf{( k g ~ h a ~}^{-1}\right)$} \\
\hline & $2012-13$ & $2013-14$ & $2014-15$ & $\begin{array}{c}\text { Pooled } \\
\text { mean }\end{array}$ & $2012-13$ & $2013-14$ & $2014-15$ & $\begin{array}{c}\text { Pooled } \\
\text { mean }\end{array}$ \\
\hline T1-RDF & 25.0 & 36.4 & 44.8 & 36.1 & 1.61 & 3.22 & 3.33 & 2.73 \\
\hline T2-FYM (10.0) & 26.3 & 37.5 & 43.9 & 36.8 & 1.80 & 3.42 & 3.79 & 3.02 \\
\hline T3-UC-I (2.5) & 23.8 & 35.4 & 44.3 & 35.5 & 1.53 & 3.26 & 3.63 & 2.82 \\
\hline T4-UC-I (5.0) & 23.8 & 38.0 & 45.1 & 36.6 & 1.74 & 3.68 & 4.14 & 3.21 \\
\hline T5-UC-I (10.0) & 29.3 & 37.4 & 46.2 & 38.1 & 2.38 & 4.07 & 4.29 & 3.59 \\
\hline T6-UC-II (2.5) & 25.0 & 34.4 & 44.4 & 35.2 & 1.67 & 3.24 & 3.40 & 2.78 \\
\hline T7-UC-II (5.0) & 26.3 & 36.4 & 44.2 & 36.0 & 1.97 & 3.54 & 3.74 & 3.10 \\
\hline T8-UC-II (10.0) & 27.8 & 36.2 & 46.0 & 36.9 & 2.24 & 3.79 & 3.95 & 3.34 \\
\hline S.Em \pm & 1.5 & 0.9 & 1.5 & 0.66 & 0.11 & 0.07 & 0.19 & 0.08 \\
\hline CD & NS & NS & NS & NS & 0.34 & 0.21 & 0.58 & 0.25 \\
\hline
\end{tabular}

* U.C. I = Urban compost from Jawahar Nagar, Hyderabad, U.C. II = Urban compost from Autonagar, Hyderabad. A common recommend dose of $120-60-40 \mathrm{~kg} \mathrm{~N}-\mathrm{P}_{2} \mathrm{O}_{5}-\mathrm{K}_{2} \mathrm{O}$ was applied to all the treatments.

*Irrigation water applied and effective rain fall was 1670, 1660 and 1480mm, during 2012-13, 2013-14 and 2014-15, respectively. 
Fig.1

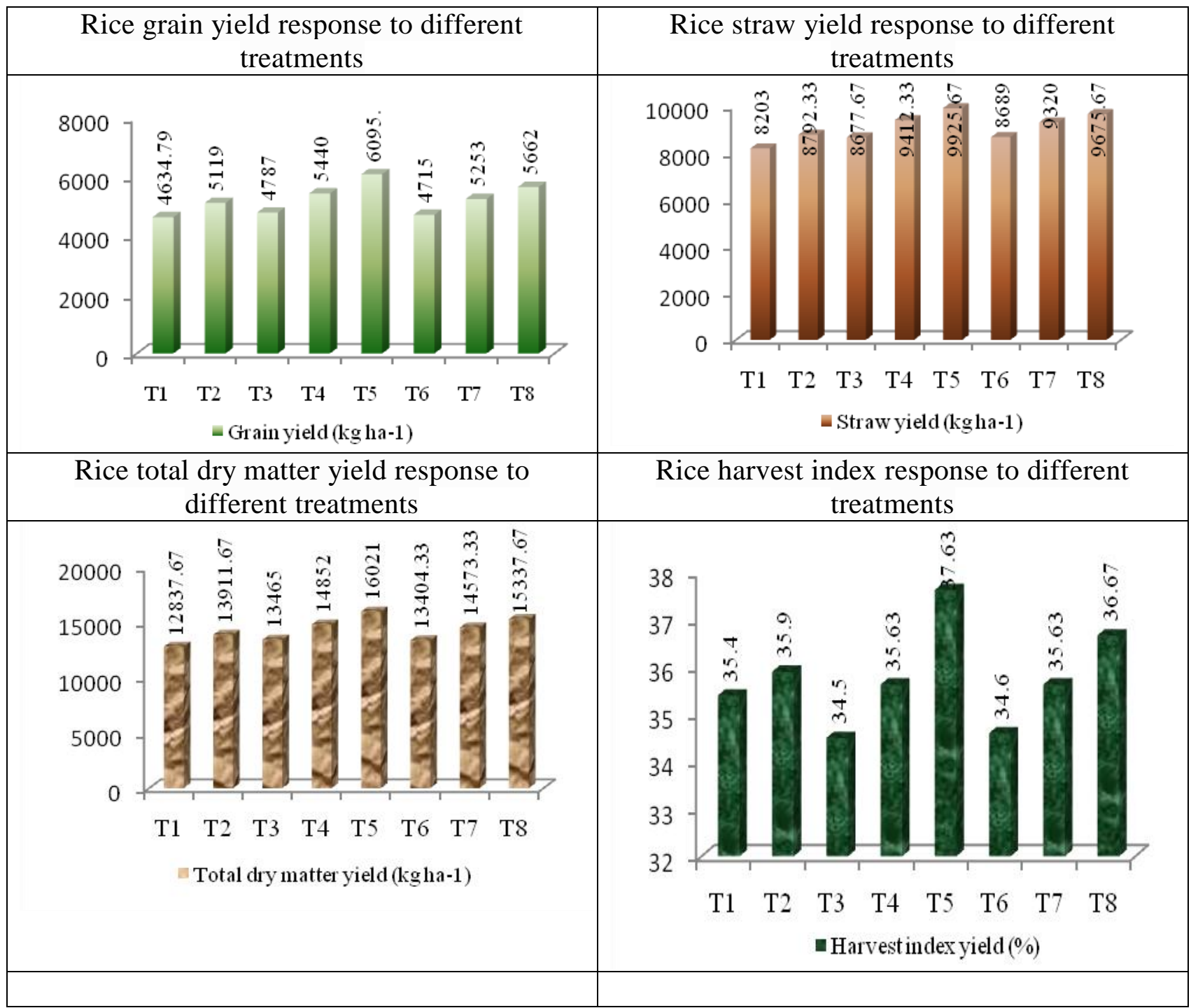

T1- Recommended dose of N,P,K ( RDF), T2-RDF+ Farm Yard Manure ( 10 t/ha), T3- RDF + Urban Compost - I (2.5 t/ha), T4- RDF + Urban Compost - I (5.0 t/ha), T5- RDF + Urban Compost - I (10.0 t/ha), T6-RDF+ Urban Compost -II (2.5 t/ha), T7- RDF+ Urban Compost -II (5.0 t/ha) and T8- RDF + Urban Compost -II (10.0 t/ha).

From the above results it is concluded that combined application of urban compost along with recommended dose of fertilizers improves the yield of rice. Application of urban compost@10t ha ${ }^{-1}$ in combination with $100 \%$ of the recommended dose of NPK fertilizers produced the maximum yield of rice variety BPT 5204 and the yield was considerably higher as compared to that obtained from the application of NPK fertilizers at the recommended dose. The higher yield obtained with integrated use of urban compost and inorganic fertilizers was attributed to increased nutrient availability and uptake, resulting in higher grain yield, straw yield, total dry matter yield, harvest index and water productivity. Therefore, application of urban compost @ $10 \mathrm{t} \mathrm{ha}^{-1}$ with $100 \%$ of the recommended dose of NPK fertilizers can be practiced for profitable rice production. 


\section{References}

Aktar, S., Islam, M.S., Hossain, M.S., Akter, H., Maula, S and Hossain, S.S.F. 2018. Effects of municipal solid waste compost and fertilizers on the biomass production and yield of BRRI dhan 50 . Progressive Agriculture. 29 (2): 82-90.

Bertoldi, M., Sequi, P., Lemmens B, Papi T (eds) (1996) The science of composting, Part 1, 1st edn. Blakie Academic and Professional, Glasgow Google Scholar.

Bhattacharyya, P and Chakraborty, A. 2003. Evaluation of MSW compost as a component of integrated nutrient management in wetland rice. Compost Science \& Utilization. 11 (4): 343-350.

Hashemimajd, K., Kalbasi, M., Golchin, A and Shariatmadari, H. 2004. Comparison of vermi compost and composts as potting media for growth of tomatoes. J Plant Nutr. 27(6):1107-1123.

Hoitink, H.A.J., Stone, A.G and Han, D.Y. 1997. Suppression of plant diseases by composts. Hort Science, 32: 184-187.

Kabirinejad, S., Hoodaji, M. 2012. The effects of biosolid application on soil chemical properties and Zea mays nutrition. Int $\mathbf{J}$ Recycl Organic Waste Agric. 1:4.

Kavitha, R., Subramanian, P. 2007. Effect of enriched municipal solid waste compost application on growth, plant nutrient uptake and yield of rice. Journal of Agronomy. 6, 586-592.

Nambiar, K.K.M. 1991. Long term fertility effects on wheat productivity. Proc. Int Conf. Maxico. DF. CIMMYT: 516-560.

Peng, S. B and Yang J. C. 2003. Current status of the research on high yielding and high efficiency in resource use and improving grain quality in rice. Chin J Rice Sci,17: 275-280.

Reganold, J.P., Robert, I.P and Parr, J.F. 1990. Sustainable agriculture in the United States. An overview sustainable Agriculture: issues, perspective and prospect in semi-arid Tropics.

Sahin, S and Bolukbasi, A. 2009. The effect on organic agriculture of insulation of rural houses in Turkey. Asian J. Applied Sci., 2: 394-401.

Schlegel, A. J., Assefa, Y., Bond, H.D., Wetter, S.M. and Stone L.R. 2015. Soil physicochemical properties after 10 years of animal waste application. Soil Sci. Soc. Am. J. 79: 711-719.

Sohrabi Yourtchi, M., Haj Seyyed Hadi, M.R and Darzi, M.T. 2013. Effect of nitrogen fertilizer and vermi compost on vegetative growth, yield and NPK uptake by tuber of potato (Agria CV.). Int J Agric Crop Sci. 5(18): 2033-2040.

Weltzien, H.C. 1989. Some effects of composted organic materials on plant health. Agric. Ecosyst. Environ., 27: 439-446.

Zinati, G.M., Li, Y.C., Bryan, H.H., Mylavarapu, R.S and Cadallo M. 2004. Distribution and fractionation of phosphorus, cadmium, nickel, and lead in calcareous soils amended with composts. J Environ Sci Health B. 39(1): 209-223.

\section{How to cite this article:}

Avil Kumar, K., K. Sadasiva Rao, M. Uma Devi and Sandeep Kumar, D. 2019. Yield and Water Productivity Response of Rice to Application of Urban Compost. Int.J.Curr.Microbiol.App.Sci. 8(12): 1872-1878. doi: https://doi.org/10.20546/ijcmas.2019.812.223 